\title{
PROBLEMS IN THE COMMERCIAL SALE IN LATIN AMERICA
}

\author{
Henry Paine CRawford*
}

According to Justinian "obligations from consent arise in purchase and sale. ... And the obligation is said to be contracted by consent for this reason, because no writing, nor the parties' presence is necessary, nor is it requisite that anything be delivered in order that the obligation arise; but it is sufficient that those who make the transaction consent. Therefore also such contracts are made even between parties who are absent from each other, for instance, by letter or by messenger." 1 Little imagination is needed to discern the elements of the international contract of sale in the preceding words.

As a general rule the transfer of merchandise constitutes the principal relationship between peoples or nations; hence, the importance of the contract of sale in all its variations. On many occasions when an American manufacturer transfers merchandise to a foreign purchaser, the former does not, at least according to his concept, enter into a contract. He "receives an order" or he "makes a sale." Numerous American manufacturers, although fully aware of the benefits due them, do not seem to grasp the significance of their legal liabilities under an international contract of sale. Stated in slightly different terminology, they appear to be totally unaware of the variety of legal recourses accessible to the foreign buyer because the latter, in the majority of cases, can be reached only by legal proceedings in his own bailiwick. Take, for example, the c. i. f. contract, probably the most widely used medium in international sales.

\section{The C. I. F. CLAUSE ${ }^{2}$}

According to our jurisprudence, the meaning of the letters "c. i. f." in an executory contract is well understood in the commercial world. They mean the cost of the merchandise, insurance thereon, and freight charges to the point of destination.

* Member of the Bars of the District of Columbia, Georgia and California. Specialist in Latin American Law, American Republics Unit, Department of Commerce. Contributor of articles on Latin American law to legal periodicals and author of various publications of the U.S. Department of Commerce dealing with the same subject. For a more complete discussion of points and authorities relied on in this article, the reader will be referred at appropriate points herein to certain relevant articles and other published writings of the author's.

${ }^{2}$ Institutes of Justinian, 3, 22 (A. D. 533); Sherman, Epitome of Roman Law (1937), \$284. All subsequent references to Roman law are based upon the preceding work of my friend, Dr. Charles P. Sherman of the Faculty of Law, Boston University.

${ }^{2}$ See Crawford, The C. I. F. Contract Interpreted by Argentine Courts (1940) 3 Comparative L. SERIES 493. 
Unless there is something in the c. i. f. contract to indicate the contrary, the seller completes his contract when he delivers the merchandise in good condition to the carrier, pays the freight, and forwards to the buyer a bill of lading, an invoice, an insurance policy, and a receipt showing payment of the freight.

Under a c. i. f. contract, the risk of loss during transit is on the buyer even though the shipper retains title until payment. If it is agreed that the goods shall be insured for the benefit of one party or the other, it seems a necessary inference that the parties intended the risk to be borne by such a party. The ordinary c. i. f. contract in which the risk is thrown upon the buyer is an illustration of this.

However, the shifting of the risk of loss during transit from seller to buyer is not the only advantage which this form of transaction affords the seller. Since terms of sale are normally "cash against documents" and since the documents may be tendered in advance of the goods' arrival, the seller is protected against the buyer's refusal to accept and pay for the goods on the ground of their failure to conform to sample or contract specification. True, the buyer may, within a reasonable time after receiving the goods, object to them and seek to rescind the sale and recover the price from the seller. However, in this situation the position of the seller who has received payment is much stronger than his position would be if he were seeking to compel a distant and reluctant buyer to accept the goods and pay their price.

\section{Conflicting Decisions as to the Buyer's Obligation}

Unfortunately, foreign interpretations of the c. i.f. contract give grounds for uncertainty whether the American seller can count on this advantage. The sharp conflict of decisions in Argentina is illustrative. The general rule in Argentina seems to be that as to liability for normal risks of the voyage and happenings at sea, the vendor is not liable for contingencies which happen subsequent to embarkation; in the $c$. i. f. sale the liability of the vendor ceases with the embarkation of the merchandise in good condition. Further, in c. i. f. sales, the burden rests upon the purchaser to show that the merchandise which was transferred to him at the point of embarkation was not of the quality agreed in order to justify a rescission of the contract and his resistance to payment of the price against delivery of the documents in accordance with the agreement.

In contrast to this, nevertheless, we have the exceptional Argentine ruling in 1923 that the c. i. f. clause does not exempt the vendor from the obligation of proving that the merchandise is of the quality agreed, and where payment has been stipulated against delivery of the documents the purchaser may refuse payment upon alleging that the merchandise landed is not of the agreed quality. Both of these holdings seem diametrically opposed to the thesis of the c. i. f. clause. ${ }^{3}$

\footnotetext{
${ }^{3}$ It is of interest to note that in 1927 the High Court of Australia (two justices dissenting) awarded damages to the plaintiff buyers on the theory that the $c$. i. f. purchaser is under no obligation to take up the documents when the goods shipped are not in fact of the description contained in the contract, even though the documents purport to represent them as being such. Dean \& Sons (Sydney) Ltd. v. O'Day Proprietary Ltd., 39 C. L. R. 330 (1927). In similar vein but blunter language the Supreme Court of Victoria laid down the rule in 1923 that where a buyer under a contract "c. i. f. e. cash against docu-
} 
Again, in I929 we find another negative Argentine interpretation of the c. i. f. clause. Although holding that the purchaser may not refuse payment of the bills nor acceptance of the merchandise, the Argentine Commercial Chamber frankly admits an exception. In the event that the purchasers have well-grounded doubts respecting the quality or quantity of the things acquired, they may demand an examination, "sole and legitimate right which jurisprudence has accorded purchasers, to the benefit of national commerce, which saw itself prejudiced in another epoch by the bad faith of foreign merchants who were bringing to port merchandise of bad quality or of a quality not specified and pretending that by virtue of the nature of the $c$. i. f. sale the purchaser was running all the risks as owner." Although the above action did not rest upon this point, and judgment was rendered for the plaintiff, it is nonetheless interesting to see this thesis appearing again in a unanimous Argentine opinion rendered six years after a similar opinion, even if only in the form of obiter dicta.

In I924 the Argentine Camara Comercial, in positive conflict with a decision rendered the previous year, declared that, in a c. i. f. contract, the purchaser, having bound himself to pay against delivery of the documents, has no right to examine the merchandise previously, even though the sale may have been by samples. The defendants argued that the rice in question was purchased by sample, and that before accepting it or paying the amount due, they should first see if it corresponded to sample. This defense, the court held, was inadmissible because the purchase was made under a c. i. f. clause, which is equivalent to receiving the merchandise in the port of embarkation. Even though the sale be effected by samples, this fact does not authorize nor accord a greater right than the filing of an action against the seller upon proof that, after having paid for the merchandise, the buyer found it of different quality than the samples. However, a prior Argentine decision rendered three weeks earlier stated that the meaning of the c. i.f. clause does not prevent the differences respecting defects of quality in the performance of the contract of purchase and sale from being resolved by expert arbitration. This would indicate that the arbitration takes place after the arrival of the merchandise at the port of destination.

Two years later (1926) we find a case in which the plaintiff alleged that the controversy involved a contract with a c. i. f. clause, that the risks were covered by insurance, and were, consequently, removed from the liability of the seller. Irrespective of these circumstances, the Argentine Camara Comercial held the plaintiff's theory inadmissible "since the c. i. f. clause cannot, in any form, weaken the right which attends the purchaser to examine the merchandise even when he can do so only after paying its price against delivery of shipping documents."

The decisions of the Argentine courts are not the only basis for distrusting broad generalizations as to the efficacy of the c. i. f. contracts in Latin American trade. Wahl, the great French authority, has always upheld the c. i. f. buyer's right to verify

ments" refuses to pay the price and take up the documents when tendered he may defend an action for nonacceptance by showing that although the documents were in order the goods actually shipped were not of the contract description. Massey v. Arlitz, [xg23] Vict. L. R. 132. (The "e" in "c. i. f. e." refers to "exchange," hence the clause becomes cost, insurance, freight and exchange.) 
the condition of the merchandise upon arrival. He goes so far as to say that "the transfer does not operate until this moment." In this he was ably seconded in 1934 by Mendonça, a Brazilian, another of the great writers of the civil law, although in rgrg the Supreme Court of Brazil had unqualifiedly sustained the significance of the c. i. f. clause.

\section{F. O. B. and F. A. S. Contracts as Alternatives to C. I. F. Contracts}

The American shipper who wishes to take no risk that payment will be delayed while controversies over the goods are ironed out should consider shipment f. o. b. or f. a. s. instead of c. i. f. The terms c. i. f. and f. o. b. are similar in that title passes in either case upon delivery to the carrier; delivery to the carrier is delivery to the buyer, and after delivery to the carrier the risk is on the buyer. For purposes of the discussion here, f. a. s. is practically the same as $f . o$. b., the only substantial difference being that in the case of the former delivery is "free alongside" the vessel instead of "free on board." The terms c. i.f. and f. o. b. are dissimilar in relation to the most essential feature of any contract-payment. This dissimilarity arises, not as a matter of law, but as a matter of practice.

The c. i. f. contract is inherently an overseas contract. Its primitive significance suggests it as a contractual medium between a domestic seller and a foreign buyer. The f. o. b. contract is inherently a domestic contract. Its terminology bluntly indicates the termination of the transaction at the cars or at the port of embarkation. To be sure, there is nothing to prevent the tender of $c$. i. f. documents to an agent of the foreign buyer at that port of embarkation for payment, nor is there any rule of law which prohibits the tender of $f . o$. $b$. documents abroad for the same purpose. The c. i. f. contract, nevertheless, has been built up as a medium of sales in overseas trade, and in all of the foreign litigated controversies coming to the writer's attention the c. i. f. documents have been tendered abroad. The latter place naturally becomes the locus of any action by the seller against the foreign buyer. The American seller must sue before distant courts to recover his price or his damages for nonacceptance.

On the other hand, the ordinary f. o. b. cars or f. o. b. (or f. a. s.) vessel transaction is usually completed by a tender of documents for payment in this country, either upon arrival by mail of the documents at the bank or other agent of the vendor at the port of embarkation, or immediately after the goods have been loaded inboard or effectively laid alongside. Blind reliance on the c. i. f. contract, unless the latter is prepared with a full knowledge of its possibilities, may prove costly. Where the American manufacturer is not desirous of investigating the peculiarities of this type of contract, the f. o. b. or f. a. s. form (for domestic use) may serve as a substitute.

\section{Delivery to Consignee Before Payment4}

Certain cases have arisen in Latin American practice whereby the consignee may obtain possession of the shipment without first accepting or paying the draft even when the draft is attached to the shipping documents. For instance, under the previous Law of Customhouses of Venezuela it was expressly prohibited to bring

- See Crawford, Trading under the Laws of Venezueza (U. S. Dep't of Commerce, 1937). 
merchandise into the country "in search of a market" (en busca de mercado) or "to the order of the captain." All merchandise had to be shipped to some specific consignee named in the shipping documents. Furthermore, "to order" shipments were afforded no protection, and, in addition to being expressly prohibited, the captain of any ship carrying merchandise to order, and so declared in the manifests and bills of lading, was subject to a fine of 500 to 2500 bolivares. Moreover, he would be deemed the lawful consignee of the "to order" merchandise and would be compelled to pay a surcharge equal to $25 \%$ of the standard customs duties chargeable against the goods.

The present Venezuelan Law of Customhouses expressly provides that the consignee whose name appears in the consular invoice is the importer of the merchandise loaded for Venezuela, and for all purposes of the law he is considered to be the owner thereof. That shipments with draft attached may be removed from the customhouse irrespective of the draft is clearly seen from the text of Chapter VI, Section II, of the law, providing, in substance, that when the importer fails to receive a certified consular invoice, the customhouse, at his request, will issue him a certified copy of the corresponding invoice, in order that the importer may prepare his declaration. Thus, even though the Venezuelan consignee does not receive his copy, this having been sent to a bank with draft attached, he may, by following the procedure outlined above, have the necessary copy made at the customhouse and withdraw the merchandise without either accepting or paying the draft.

As a result of existing circumstances, many banks in Venezuela have refused to handle documents with drafts attached, recommending instead that merchandise be consigned to a reliable customs broker with instructions to deliver to the ultimate consignee only against presentment by the latter to the customs broker of a delivery order directed to the broker, with draft attached, and bearing instructions that the merchandise will be released to the ultimate consignee after acceptance or payment.

\section{The Latin American Straight Sale ${ }^{5}$}

The United States manufacturer who distributes his products from branches or warehouses situated in Latin American nations will doubtless most frequently have occasion to sell to his Latin American customers directly without attempting to reserve a security interest by the use of documents of title. In connection with such straight sales, it will be important for him to know what remedies he may invoke against a delinquent buyer, or what remedies the Latin American buyer may assert against him. Knowledge of such remedies will be equally important when the United States concern is a purchaser in the Latin American market.

In civil law, the protection afforded the seller (or the buyer) under a commercial contract of purchase and sale is usually referred to as a "right of the seller" (or of the buyer). The "remedy" is, in reality, the means by which the "right" is enforced.

Of course, the seller or the buyer has his "remedies" in civil law. Under a c. i. f. contract the seller may sue for specific performance, that is to say, to compel defendant to accept the merchandise and pay the price, or, in ordinary sales, he may sue for his price or make use of the judicial deposit, described below, or seek such

\footnotetext{
${ }^{5}$ See Crawford, The Contract of Sale in Latin America (1939) 6 Оноо ST. L. J. .
} 
other remedies as the facts may warrant. The buyer, on the other hand, may sue for rescission, specific performance or for damages because of delay, or he may defend an action for the price when the thing delivered is not of the contract description. The preceding enumeration of "remedies" is purely informative, not exhaustive.

\section{Rights of the Seller}

Right of Sale: Latin American laws very generally confer upon the seller the right to sell the goods for the account of a defaulting buyer. Thus, if the Venezuelan buyer fails to perform his obligation, the seller has the right to cause the sale of the subject matter of the contract or to deposit it with an accredited business house, and in the absence of the latter, with a person of responsibility, all for the account of the buyer. The sale shall be made at public auction, or at the current price if the thing has a price on the exchange or in the market, through the medium of a dealer or broker, as the case may be, or, in the absence of both, through the medium of a person designated by the Court of Commerce (Iuez de Comercio). The seller has the right to demand payment of the buyer of the difference between the price obtained and the price agreed upon in the contract, as well as indemnity for the damages suffered. On the other hand, if the Venezuelan seller fails to perform his obligation, the buyer has the right to buy the thing in the manner established above, for the account of the seller, and to be indemnified for the damages suffered. The contracting party who makes use of the above-described rights must give notice immediately to the opposite party.

Judicial Deposit: The judicial deposit in civil law (deposito y reconocimiento de efectos mercantiles) is a simple proceeding similar to deposits in court of American common law. We have seen that if the civil law buyer, without just cause, refuses to accept the effects purchased, the seller may sue for specific performance or rescission of the contract, making use of the judicial deposit of the merchandise in the first case. If, as a consequence of such circumstances, or for any other analogous cause, it becomes necessary to deposit commercial effects, the party so moving addresses a petition in writing to the court (usually the Court of Commerce), giving a complete description of the things whose deposit is sought, and designating the person who is to act as depositary. The latter must be (under Cuban law) a matriculated merchant, if there is one in the place, or when none is available, a taxpayer who pays so large a contribution that the court will accept him as a guarantor, taking into consideration the value of the deposit and the conditions in the locality.

In any case, it lies within the discretion of the court to evaluate the guaranty given by the depositary designated by the party moving the deposit; if the court believes another should be appointed, he will do so, subject to the provisions of the law of civil procedure.

Vendor's Lien: The civil law also provides for a vendor's lien. As long as the effects or merchandise remain in possession of the seller, the latter has the right to retain them until full payment of the price with interest. The vendor's lien holds good even in case of the bankruptcy of the buyer. 
Stoppage in Transit: If, between the date of the contract and the moment of delivery, the assets of the buyer have notoriously decreased, the seller is not bound to deliver the thing sold even though he has granted a period of time for payment, unless sufficient security be given. During the course of the voyage and even after its arrival at destination, if still found in stations, warehouses or docks, the merchandise may be replevied by the seller where the buyer requests a creditors' agreement or is adjudged a bankrupt.

Determination of Quality: According to Argentine practice, when the sale is made by samples or by a quality "known in the uses of commerce," then, if the buyer refuses to accept the goods for lack of conformity, they will be examined by experts, who, taking into consideration the terms of the contract and comparing the goods with the samples, will declare whether the goods are fit for acceptance. If the declaration is in the affirmative, the sale will be treated as consummated, the goods remaining for the account of the buyer; if to the contrary, the contract will be rescinded without prejudice to a claim for damages accruing to the buyer by reason of special agreements entered into with the seller.

\section{Rights of the Buyer When Goods Are Defective or Damaged ${ }^{6}$}

In the sale of things not in sight and which are to be remitted to the buyer by the seller, a condition which terminates the principal obligation is always understood as stipulated in case the thing may not be of the agreed quality. Moreover, in all purchases of things not in sight or which cannot be classified according to a quality "determined and known in commerce," the reservation to examine them and freely rescind the contract if the goods do not suit him "is presumed in the buyer." He also has the same faculty if he has reserved to himself, by an express clause, the right to try the goods purchased. In either case, however, if the buyer delays the examination or trial more than three days after notice by the seller, his right is of no legal effect.

Risk of Loss or Deterioration: Under modern civil law, unlike the Roman law, ${ }^{7}$ the loss or deterioration of the subject matter before its delivery by an unforeseen accident or without negligence on the part of the seller, enables the buyer to rescind the contract, unless the seller has become a depositary of the merchandise, in which case the liability of the seller is limited to that arising from the contract of deposit. This is similar to our bailment, and arises when the buyer, without just cause, refuses to accept the thing purchased. The seller may then demand performance or rescission of the contract, depositing the subject matter judicially in the first case. The judicial deposit may also be utilized by the seller whenever the buyer delays taking charge of the merchandise. In such cases, the expenses originating from the deposit will run for the account of the party at fault.

Even where there has been no judicial deposit, the risk may be transferred to the

${ }^{\circ}$ See Crawford, supra note 5.

'Under Roman law, the "risk of the thing sold immediately passes to the buyer, even though the thing has not yet been delivered to him. Therefore if a slave die . . or a house be destroyed wholly or partly by fire ... the loss falls upon the buyer, who must pay the price, even though he has not received the things. For the seller is not liable for anything which happens without his fraud or negligence." 
buyer. Thus, under Cuban law, the damages and shrinkage of the subject matter after the contract has been perfected and the seller has the goods at the disposal of the buyer, in the place and at the time agreed upon, run for the account of the buyer except in cases of fraud or negligence.

On the other hand, the damages and shrinkage which the merchandise may suffer, even by a fortuitous happening (caso fortuito), run for the account of the seller if the sale has been made according to number, weight or measure, or where the thing sold is not certain and determined by marks or signs which identify it; if, by express agreement or commercial usage, taking into consideration the nature of the thing sold, the buyer has the right to inspect or examine it beforehand; or if the contract contains the provision that delivery will not be made until the thing sold acquires the conditions stipulated. In any case, if the things sold perish or deteriorate while they are under the control of the seller, the latter must return to the buyer the part of the price already received.

Lesión: In conformity with the thesis of modern civil law contract of purchase and sale, commercial sales will not be subject to rescission because of lesion. The latter has a meaning peculiarly its own, other than that usually ascribed to it in the ordinary dictionary. It is suggested that the nearest approach to a correct translation into English would be "partial failure of consideration." Lesión is defined by Escriche as "the damage or prejudice which is caused in contracts for a valuable consideration, and especially in purchases and sales, by not making them in their just price."

There were two degrees of lesión under early Spanish law, lesion enorme and lesion enormisima. The former is the degree of damage suffered by "having been deceived in something less than the half of the just price"; the latter, "in much more than the half of the just price." However, the lesion must be accompanied by deceit (engaño); upon proof of the lesion and the deceit, the injured party may claim the return of the "excess of the just price which the thing had at the time of the sale, or that there be given back what is lacking up to this, or that the contract be rescinded and annulled, each one taking what he gave to the other."

Statute of Limitations: ${ }^{8}$ The buyer who at the time of receiving the thing sold, examines it to his satisfaction, has no right of action for recovery against the seller for a defect of quantity or quality. However, the Cuban buyer, even after taking delivery, has his right of action against the seller for a defect in the quantity or quality of merchandise received in bales or packed, provided he bring his action within four days after date of receipt, and provided further that the damage does not arise from a fortuitous happening, an inherent defect (vicio propio de la cosa), or fraud. In such cases, the buyer may elect as to rescission or specific performance, holding the seller liable for the damages caused by the defects or shortages. Nevertheless, the Cuban seller may avoid such a claim by insisting that the inspection for quantity and quality be made by the buyer in the act of delivery.

The buyer who fails to file his claim for hidden defects (vicios internos) usually

${ }^{8}$ See Crawford, Venue of the Action Ex Contractu in Latin America (1941) 15 U. of CiN. L. Rev. 277. 
within thirty days after delivery loses all right of action to recover against the seller for this cause. However, the party who has proceeded with malice or fraud must respond for the damages thus caused, without prejudice to the corresponding criminal proceedings, and in every commercial sale, the seller is bound to respond to the buyer for his warranty of title, peaceful possession, and against hidden defects.

\section{The Instalment Sale}

The United States manufacturer or distributor engaged in the sale of goods which are customarily sold in this country under conditional sale or chattel mortgage contracts will not find available in Latin America the same legal implementation for instalment selling which has been developed in the United States. Typical of the legal devices resorted to in Latin American instalment sales are those used in Argentina and Venezuela, which are briefly described below, together with a reference to the legislation in Chile and Mexico in aid of the instalment seller.

Argentina: ${ }^{9}$ In an instalment or conditional sale two questions immediately arise under Argentine law, the first involving the legality of such an agreement as between the immediate parties, and the second, the rights of the vendor as against third parties. There are no references in the Argentine Code of Commerce providing for a transaction of this type, and the Argentine Civil Code prohibits it. Argentine vendors have consequently resorted to a form of hire-purchase agreement with the payments described as rentals; however, the validity of the hire-purchase agreement in Argentina has yet to be definitely determined by the courts. As a result, Argentine conditional sales should be based upon sufficient security for the purchase price and should be supervised by competent counsel.

Because of dissatisfaction with the hire-purchase method of selling, distributors in Argentina were quick to attempt reliance upon the supposed advantages of Law No. 8644 of October 19, 1914, known as the law of prenda agraria, in reality, an agricultural pledge. However, the legislative background of this law proves conclusively that it was intended to cover only agricultural machinery and not things ordinarily sold to consumers at large. As a consequence there have been conflicting judicial decisions both as to the legality of the subject matter and the protection of the vendor against third-party claimants under sales contracts based on this law. It is therefore necessary to take every precaution in making sales under its provisions.

Venezuela: ${ }^{10}$ As a matter of actual commercial practice, we find six forms of contract or medium by means of which things are sold in Venezuela subject to the reservation of title. They are:

r. The simple invoice, at the foot of which appear the conditions of the sale; the invoice is supported by a series of drafts drawn by the vendor against the vendee and accepted by the latter.

2. The formal contract of conditional sale, executed by a merchant, and supported by a series of drafts drawn to the order of the vendor.

3. The formal contract of conditional sale, executed by an acceptance corporation and supported by an adequate number of bills of exchange issued by the vendor and accepted by the vendee.

\footnotetext{
${ }^{\circ}$ See Crawford, Trading under the Laws of Argentina (U. S. Dep't of Commerce, 1935).

${ }^{10}$ See CRAwFord, op. cit. supra note 4 .
} 
4. The lease contract, with space provided for a contract of guaranty or surety.

5. The pure and simple lease contract without the supplementary contract of guaranty, but supported by drafts or promissory notes.

6. The special form of lease contract used by motor car distributors, supported by drafts issued by the vendor-lessor against the vendee-lessee and accepted by the latter.

As a matter of legal theory, in the sale of movable property on the instalment plan there is no law in Venezuela which absolutely guarantees the rights of the vendor when the thing sold has been delivered to the purchaser. It is customary to make use of some one of the forms described above as the legal foundation of the Venezuelan conditional sale, but if the purchaser has transferred the thing to a third party for value without notice, or has given it in payment of a debt, or has been declared bankrupt, the legal position of the seller is seriously vulnerable.

Chile and Mexico: Chile has specifically legislated on the subject of the conditional sale and the industrial pledge, whereas Mexico has modernized its Civil Code * to admit the conditional sale and to give protection against third-party claims, provided the contract is registered. However, since the individual states of Mexico are autonomous, similarly to the states of the United States, reference must be had to the respective state laws before committing one's self to a conditional sale in Mexico.

\section{Venue and Choice of Law in Contract Litigation ${ }^{11}$}

When a contract of sale is entered into between a seller (or buyer) in the United States and a buyer (or seller) in Latin America, questions will arise, in the event of controversy leading to litigation, as to which law should govern such litigation and where it should take place. In the answer to these questions, much may depend on where the place of contract is found to be or whether there has been a place of performance, a place of trial, or a special domicil stipulated in the contract.

Place of the Contract: According to Clovis Bevilaqua, the famous Brazilian jurist, the determination of the place where the contract was concluded is of the utmost importance in private international law because on it depends the law to be applied to the juridical relations of the parties. This brings about a decided conflict of laws in answering the question: Where was the contract perfected? To determine this one must ask: When was the contract perfected? A conflict may be found even within the respective codes of the same country. The Mexican Civil Code of 1928 provides that the contract is formed at the moment in which the proponent receives the acceptance, whereas the Mexican Code of Commerce holds to the theory of transmission appearing in the Spanish Code of Commerce of $188_{5}$, viz., the contract is perfect as soon as the correspondence is answered accepting the offer. Thus, in Mexican commercial law a mercantile contract is perfect as soon as the offer is accepted by the offeree, although in Mexican civil law the contract is perfect only when the offeror receives the acceptance.

Place of Performance: The civil law theory is that the designation of the place of performance is equivalent to a submission of the parties to the courts of that place.

\footnotetext{
${ }^{11}$ See Crawford, supra note 8.
} 
The civil law theory of venue based on performance goes far beyond the common law, actually laying the venue of the action at the place of performance of the contract in preference to any other forum, irrespective of the domicil of the defendant, unless otherwise stipulated, whereas the trial court under the common law merely presumes to apply the law of the place of performance.

The civil law method is the simpler of the two. Where the place of performance is discernible from the contract, either party knows where he may bring his action; he does not have to pursue his defendant who, under the thesis just described, submits himself to the courts of the place of performance when he signs the contract. It is not required that the contract recite "this contract is to be performed in such and such a place." It is sufficient if the place of performance can be ascertained from the context.

Submission of the Parties: Probably the most satisfactory method of insuring the territorial jurisdiction most advantageous to the parties, or to one of them, either in civil law or under the common law, is to insert a clause to the effect that the courts of such and such a place shall have jurisdiction over any controversies arising from the contract, or by voluntarily naming a special domicil for purposes of the contract. A civil law court is competent to take jurisdiction of any civil action if the parties submit themselves expressly or tacitly. Such a submission, however, may be made only to a court having jurisdiction of the same class of controversies and in the same grade.

Domicil: Under civil law contract practice, it is generally permissible for the contracting parties to name a special domicil for purposes of the contract. A domicil for a determined transaction having been stipulated by the parties, the latter may submit the controversies arising therefrom to a competent court of the domicil designated. But where the debtor has waived his domicil he may be sued wherever he may be found, thus placing the latter in the same situation as a defendant who has no known domicil or residence.

"The painter works with a great palette of colors, the etcher, with lines and lights and shadows, the musician, with majestic chords and lilting melodies, but the lawgiver must confine himself to words, words, words. ... Although it is impossible by its nature for the law to be exact, it is not at all impossible for it to be precise about the words it uses. And for a lawyer to attempt anything less than precision is to go the way of chaos." Verbum sapiens! Do not rely upon the American doctrine of stare decisis as a sort of juridical robot to prosecute your client's suit abroad when, in many cases, it might have been avoided. Convince your client, when he is about to enter into a c. i. f. sale, that the letters "c. i.f." at the top of the contract form is not all he needs for protection. Remember the civil law theory that the court of the place of performance has preferred jurisdiction over any other court in the absence of contrary stipulations. Remember that the place of the contract in civil law is of greater importance than under the common law, and arrange your contract accordingly. 